\title{
PESANTREN DAN PENGEMBANGAN KURIKULUM KEWIRAUSAHAAN: Kajian Pesantren Roudahtul Khuffadz Sorong Papua Barat
}

\author{
Ismail Suardi Wekke \\ Sekolah Tinggi Agama Islam Negeri (STAIN) Sorong Papua Barat \\ iswekke@gmail.com
}

\begin{abstract}
Pesantren is a unique instrument of Indonesian educational system. Environmental adaptations enhance pesantren to modify institutional change and development. Therefore, this research will explore bow pesantren widen the curriculum in term of enterprenurship. This study was conducted in pesantren Roudhotul Khuffadz. It is located in Sorong, West Papua province, eastern part of Indonesia. In depth-interview and non participant observation were attended in collecting data. In term of efforts to identify data validity, the research was extended from three months to six months. The study shows that the pesantren Roudhotul Khuffadz was presented many examinations and discussion in developing its curriculum. In addition, they decided to empower curriculum with entrepreneurship aspects. This decision was concluded to extend local needs and students skills in enlarging their opportunities after school age. Finally, this study recommends identifying socio-cultural in pesantren environment in order to understand curriculum improvement.
\end{abstract}

Keywords: Pesantren, Curriculum, Entrepreneurship

\begin{abstract}
Abstrak
Pesantren merupakan instrumen sistem pendidikan Indonesia yang unik. Adaptasi lingkungan mendorong pesantren untuk selalu melakukan pembaruan dan pengembangan kelembagan. Oleh karena itu, penelitian ini akan melakukan pembahasan bagaimana pesantren memperluas cakupan kurikulum dalam konteks kewirausahaan. Studi ini dilaksanakan di pesantren Roudhotul Khuffadz, terletak di Sorong, Provinsi Papua Barat, bagian timur Indonesia. Wawancara mendalam dan pengamatan tidak berpartisipasi digunakan dalam pengumpulan data. sebagai upaya untuk memastikan validitas data penelitian, maka waktu pengumpulan data diperpanjang dari tiga bulan menjadi enam
\end{abstract}


bulan. Penelitian menunjukkan bahwa pesantren Roudbotul Khuffadz melakukan beberapa kajian dan diskusi dalam rangka pengembangan kurikulum. Selanjutnya, mereka memutuskan untuk memperkuat kurikulum dengan aspek kewirausahaan. Keputusan ini dibuat dengan memperhatikan kebutuban lokal dan juga untuk memberikan keluasan kesempatan bagi siswa setelah umur sekolah. Akbirnya, penelitian ini memberikan rekomendasi untuk melakukan penelitian lanjutan berkenaan dengan sosio-kultural lingkungan pesantren dalam rangka memahami penyempurnaan kurikulum.

Kata kunci: Pesantren, Curriculum, Entrepreneurship

\section{Pendahuluan}

Sebagai lembaga yang khusus melakukan kajian keagamaan (tafaqqub di al-din) pesantren juga tidak melepaskan diri dari lingkungan sosial. Dinamika pesantren dalam pandangan Mastuhu (1994) menjadi perjuangan pesantren dalam memantapkan identitas dan kehadirannya di tengah-tengah bangsa. Walaupun pesantren lebih dulu hadir dalam konteks kebangsaan, tetapi wujud pesantren yang menyelenggarakan sistem pendidikan kemudian menjadi salah satu subsistem pendidikan nasional. Kehadirannya tentu untuk memenuhi kebutuhan nasional dengan tujuan utama pencapaian pada tujuan pendidikan nasional. Ini akan semakin mudah tercapai, jikalau pesantren senantiasa mengukuhkan identitas kelembagaan dalam rangka mengisi khazanah kebudayaan bangsa. Keberadaan pesantren selanjutnya menjadi partisipasi masyarakat untuk turut memberikan sumbangan bagi kemajuan anak-anak bangsa.

Penelitian tentang pesantren telah menjadi perhatian para sarjana diantaranya Dhofier (1982), Mastuhu (1994). Mereka memberikan gambaran tentang pesantren dengan konteks di tahun 1980 sampai 1990 dimana pesantren berperan sebagai pendukung pertumbuhan dan perkembangan pendidikan Indonesia. Adapun pesantren sebagai kajian, juga dilakukan oleh para sarjana yang berasal dari perguruan tinggi luar negeri seperti Van Bruinessen (1995), Lukens-Bull (2001), Pohl (2006), Sementara itu, penelitian yang mutakhir tentang pesantren dijalankan antara lain Raihani (2012), Saniotis (2012), Izfanna dan Hisyam (2012), Vignato (2012), 
Hamdi dan Smith (2012). Dari kelima penelitian tersebut berkisar kepada multikulturalisme, inovasi pesantren dalam hal pengelolaan lingkungan, peran pesantren dalam penyelesaian konflik dan bencana, pendidikan karakter. Adapun penelitian Buresh (2002), Permani (2009) keduanya mengkaji pesantren sebagai kekuatan ekonomi. Tujuh penelitian mutakhir tentang pesantren sebagaimana dituliskan di atas, sebatas menggambarkan kekuatan pesantren sebagai institusi. Untuk itu, penelitian tentang kurikulum pesantren yang berhubungan dengan pengembangan kearah kewirausahaan belum dilakukan pembahasan komprehensif.

Publikasi selama ini masih seputar pesantren dalam konteks pembaruan pendidikan di pulau Jawa. Berbeda dengan pulau Papua. Dimana tempat ini dikenal dengan aksi kekerasan dan pemberlakuan daerah operasi militer di zaman Orde Baru. Dalam praktiknya, Pesantren Roudhatul Khuffadz merupakan salah satu pelopor pendidikan Islam di daerah tersebut dimana muslim merupakan minoritas. Tidak saja dalam pengelolaan proses pendidikan dan pengajaran. Tetapi ada upaya yang perlu menjadi perhatian dimana, pengembangan kurikulum diarahkan untuk memenuhi kebutuhan lokalitas. Alam Papua yang membentang dengan keluasan tanahnya menjadi tantangan tersendiri bagi penduduknya. Untuk itu, pesantren ini melakukan upaya terobosan dengan melakukan pengembangan pendidikan berwawasan kewirausahaan.

Pertanyaan utama penelitian ini adalah bagaimana penerapan inovasi kurikulum pembelajaran pesantren Rodhotul Khuffadz dengan pengembangan pada sisi kewirausahaan. Untuk itu, maka makalah ini akan mengungkapkan pembahasan mengenai pengembangan kurikulum dikaitkan dengan pilihan pesantren untuk menekankan pada aspek kewirausahaan di Pesantren Rodhotul Khuffadz, Sorong. Papua Barat.

Signifikansi penelitian ini dalam kajian pendidikan dapat ditinjau dari tiga hal yaitu pertama, sebagai laporan penelitian lapangan tentang konseptualisasi pendidikan kewirausahaan dalam institusi pendidikan Islam. Kedua, dengan kondisi lokal yang tidak bisa melepaskan diri dari pergolakan nasional, maka praktik yang dijalankan dalam lembaga pendidikan Islam menjadi perlu ditelaah, agar kesinambungan antara masa lalu dan masa depan menemukan 
titik temu yang disesuaikan dengan kebutuhan zaman. Ketiga, kehidupan sehari-hari tidak bisa melepaskan diri dari urusan dua hal yaitu produktivitas dan wirausaha. Dengan demikian, suasana pembelajaran yang mengedepankan inovasi dan kreatifitas perlu dibangun. Adanya kajian ini, akan mengidentifikasi bahwa pendidikan Islam sesungguhnya tidak melepaskan diri dari realitas masyarakat. Justru dengan kompleksnya permasalahan, kemudian pesantren justru menjadi solusi di tengah-tengah kegamangan lembaga pendidikan lainnya.

Walaupun penelitian pesantren telah menjadi daya tarik tersendiri bagi banyak kalangan, tetapi penelitian serupa belum dijalankan pada penelitian terdahulu. Kekhasan penelitian ini terletak pada tiga hal yaitu pertama penelitian ini mengkhususkan diri pada perkembangan pesantren di daerah minoritas muslim. Kedua, kajian pesantren belum mengidentifikasi pada persoalan kurikulum. Ketiga, aspek kewirausahaan menjadi unsur penting dalam penelitian ini. Dengan demikian, penelitian tetap menjadi relevan dan kontekstual untuk mengkaji pendekatan pembelajaran, pengembangan kurikulum dalam hubungannya dengan semangat kewirausahaan di pesantren.

Penelitian ini, menemukan makna dalam beberapa hal yaitu (1) Merumuskan teori-teori atau konsep kependidikan dalam konteks Papua Barat. (2) Memperkaya teori ataupun konsep yang telah ada sebelumnya. (3) Menguji aplikasi dari berbagai teori atau konsep pendidikan dalam praktik di lapangan. (4) Untuk mendapatkan inovasi dari pelbagai teori, konsep ataupun praktik kependidikan termasuk bagaimana keberlanjutan pola pendidikan.

\section{Pesantren dan Pemberdayaan Masyarakat}

Sejarah asal mula pendirian pesantren diuraikan oleh para peneliti dengan informasi yang beragam. Dhofier (1982) menjelaskan bahwa pesantren telah hadir sejak zaman kolonial. Adapun Boland (1985:14-27) menggambarkan dalam masa pemerintahan colonial, pesantren menjadi inti pasukan dengan menggabungkan pasukan Hisbullah ke dalam kesatuan tentara. Selanjutnya ini menjadi cikal bakal bagi pendirian Tentara Nasional Indonesia. Bahkan dalam abad ke-15, Islam telah menggantikan dominasi agama Hindu. 
Adapun kerajaan Demak hadir sejak abad ke-16 dengan mengislamkan pulau Jawa. Sementara Majelis Ulama Indonesia (1986) menguraikan data bahwa pesantren di Jawa, Dayah di Aceh, Surau di Padang telah hadir sejak abad ke-13. Dengan demikian, dari penelusuran sejarah ini dapat kita lihat walaupun ada perbedaan pandangan kapan tepatnya pesantren mulai berada sebagai institusi pendidikan di Indonesia atau Nusantara, tetapi pergolakan pesantren tentu sudah mengalami fase yang tidak pendek.

Bukan saja sorotan positif yang diterima pesantren. Bahkan kerap aksi kekerasan dihubungkan dengan pesantren. Adanya aksiaksi kekerasan yang dilakukan alumni pesantren, maka pesantren kerap mendapatkan tudingan sebagai sarang teroris. Pada praktiknya, Lukens-Bull (2001) justru sampai pada kesimpulan bahwa jihad yang dijalankan oleh para santri dan kiyai adalah jihad jalan damai (peacefull jihad). Dimana pesantren justru menjadi tempat bersemainya anak-anak muda dengan pengetahuan keagamaan yang mumpuni. Merekalah yang kemudian pada saatnya, menjadi pemimpin bangsa sekaligus menjadi inspirator bagi perubahan dalam konteks lokal dan kemudian juga menginspirasi dalam skala nasional. Bahkan di dunia internasional mereka menjadi pendorong bagi usaha-usaha perdamaian. Jika melihat kasus kekerasan yang trejadi, maka itu bukan pola yang dikembangkan pesantren.

Unsur utama pesantren terletak pada kiyai dan santri. Dhofier (1982) dan Mastuhu (1994) menjelaskan relasi antara kiyai dan santri sebagai hubungan yang tidak berjalan searah saja. Tetapi justru dengan pola-pola pengajaran badongan dan sorogan kemudian menjadi interaksi timbal balik dalam proses pembelajaran. Unsurunsur pesantren seperti kiyai, santri, masjid, pondok, dan kitab Islam klasik (kitab kuning) saling bersinergi dalam proses pengajaran. Di awal pengembangan pesantren hanya ada pendidikan secara informal di masjid. Ketika ide kemoderenan masuk ke dalam pesantren, maka bertambah sistem pendidikan yang berbentuk klasikal. Basyir (1999) menjelaskan bahwa pendirian Gontor pada tahun 1926 menjadi pionir bagi kelembagaan pesantren secara modern. Dimana sebelumnya tidak ada pelaksanaan pendidikan yang menekankan kepada penguasaan bahasa Arab dan Inggris. Pondok Moderen Darussalam Gontor yang kemudian populer 
dikenal dengan Gontor memperkenalkan prinsip-prinsip modern dalam pendidikan Islam Indonesia. Ini berkembang sampai keluar pulau Jawa, dimana alumni Gontor tidak sebatas di pulau Jawa semata-mata tetapi juga bahkan dari luar negara seperti Malaysia, Thailand, Brunei Darussalam, dan Singapura.

Tantangan utama lembaga pendidikan dimanapun adalah bagaimana melakukan proyeksi pendidikan untuk masa depan. Dengan demikian, penetapan kurikulum sesungguhnya bagian dari perancangan masa depan tersebut. Bukan justru untuk menelisik masa lalu. Jika masa lalu digunakan untuk pembelajaran masa kini dan masa depan, maka kontekstualisasi kurikulum menemukan bentuknya yang ideal. Proses pengembangan kurikulum memerlukan adanya kontak sosial dalam bentuk interaksi sosial. Untuk itu, proses pembentukan kurikulum dijalani dalam bentuk proses sistematik dan terstruktur serta membentuk suatu sistem. Ada beberapa hal yang perlu diperhatikan antara lain, konteks ide, pola interaksi, sikap individu, pemahaman tentang budaya dan orientasinya, nilai dan keyakinan, dan serangkaian faktor psikologis. Kurikulum harus menjadi respon atas keperluan masyarakat. Bahkan kurikulum dibentuk dengan pendekatan pembelajaran sebaya (Riese, Samara, dan Lillejord, 2012). Termasuk dalam proses tersebut, pembentukan kurikulum dengan mengidentifikasi dinamika konflik (O’Sullivan:2006).

\section{Pengembangan Kurikulum Pesantren}

Perkembangan pesantren dimulai dari langgar, mushollah dan masjid. Ordonansi 1905 ketika di bawah pemerintahan kolonial, justru berupaya menghambat keberadaan pesantren. Sementara itu, umat Islam dengan semangat swadaya justru melakukan pengembangan pesantren berdasarkan kepada kemampuan komunitas. Pengembangan dari masjid inilah yang tidak mampu dibendung oleh penjajah. Sampai pada kemerdekaan Indonesia 1945, empat tahun setelahnya 1949 pemerintah Republik Indonesia memberikan perluasan bagi pelaksanaan pendidikan secara umum. Ini menjadi salah satu titik penting bagi perkembangan sejarah pendidikan Islam Indonesia. Dimana pemerintah justru memberikan tempat bagi adanya pengajaran agama Islam di sekolah-sekolah (Zuhairini: 1997:150). 
Dalam perjalanan kemerdekaan Indonesia dimulai 1945, pesantren kemudian melakukan adaptasi dan pengembangan kelembagaan. Sehingga pesantren menjadi pusat-pusat pendidikan masyarakat (Ziemek:1986:251). Ini menunjukkan bahwa pesantren berbasis pada masyarakat. Kelangsungan pendidikan pesantren untuk melanggengkan nilai-nilai yang hidup dalam masyarakat itu sendiri. Ini juga adalah hasil dari adaptasi perkembangan lingkungan. Dengan keikutsertaan masyarakat dalam pengelolaan pendidikan, maka akan memberikan fungsi pendidikan yang berakar dari masyarakat dan di dalam kebudayaan (Tilaar:2010:175). Kelembagaan pesantren mempunyai kekhasan masing-masing dalam merespon modernisasi. Jamhari (2006:171-201) mengemukakan bakan dalam kondisi umat Islam dimana secara kuantitatif merupakan minoritas, mereka tidak kehilangan daya juang dan daya gerak untuk melakukan transformasi. Sebagaimana dicontohkan dalam pesantren dan madrasah yang ada di Bali.

Islam Indonesia dipandang sebagai Islam mayoritas. Tetapi di Bali, Papua, Nusa Tenggara, justru secara kuantitatif Islam merupakan agama minoritas. Demikian pula kajian pesantren, selama ini dijalankan di wilayah-wilayah dengan pemeluk Islam dalam skala mayoritas. Kajian Islam di daerah minoritas sebatas penelitian tentang harmoni (Mujahidah:2010), dakwah (Fatimah:2012 dan Sukman: 2010) kepegawaian (Likewati:2011) Islamisasi (Fatimah:2011) tokoh agama dan politik (Sunatar:2011). Adapun penelitian tentang pesantren dilaksanakan oleh Huzain (2010), Widodo (2010) dan Satir (2011). Ketiga penelitian tersebut masing-masing menguraikan hal-hal pendidikan demokratis-humanis, pelayanan pendidikan dan perilaku peserta didik. Huzain dan Widodo memilih subyek penelitian di pesantren yaitu Pesantren Darul Istiqomah dan Pesantren Emeyodere. Sementara Satir di madrasah Guppi, Sorong.

Salah satu komponen utama dalam proses pembelajaran pesantren adalah formulasi kurikulum. Dalam proses perencanaan dibagi dalam dua tahap yaitu analisis kebutuhan di masa akan datang dan penetapan program. Kedua tahapan ini untuk mengantisipasi masa depan dan bukannya untuk masa sekarang apalagi masa lalu. Perjalanan sejarah menunjukkan bagaimana proses pesantren yang dimulai dari pendidikan yang dilaksanakan 
di masjid, tetapi dalam mengantisipasi kondisi kekinian, pesantren kemudian secara formal membentuk kurikulum. Dengan ditetapkannya kurikulum, maka itu berarti analisis pembentukan sumber daya manusia yang akan dilakukan sudah menjadi pedoman tersendiri. Tantangan ini merupakan usaha yang berkelanjutan. Tidak berhenti dalam proses penetapan semata-mata tetapi diperlukan usaha dalam pemantauan efektifitas dan efeisiensi (Sealey, Robson dan Hutchins, 1997:79-89).

Salah satu terobosan mutakhir bagaimana pendidikan menyahuti perkembangan dunia bisnis dan wirausaha. Pendidikan kewirausahaan dalam skala benua Eropa mulai menjadi pelajaran tersendiri (Johansen dan Schanke, 2012). Ini merupakan respon dari proses pendidikan yang selama ini lebih menekankan kepada pengajaran semata-mata. Ketika ada pergeseran menjadi pembelajaran, maka peran aktif siswa kemudian distimulasi salh satunya melalui pendidikan dengan perhatian kepada kewirausahaan. Tentu bukan saja diperlukan pengetahuan tentang hal tersebut. Tetapi diperlukan juga ada wahana untuk mempraktikkan apa yang menjadi pengalaman belajar yang sementara hanya dalam bentuk teori. Proses belajar yang diwujudkan saat ini tentu berbeda dengan apa yang kita jalankan di masa lalu. Ada perubahan dalam lingkungan, kecendrungan yang berbeda, produk baru dan proses teknologi yang memberikan dampak bagi keberadaan pendidikan (Rosiers, Dubé, dan ThériaultL:2011). Dengan demikian, ada tatanan nilai baru yang tentunya orientasi pendidikan bergeser pada aspek yang lain.

Dari uraian di atas, maka kajian ini tetap menjadi kesinambungan bagi penelitian terdahulu. Namun demikian, sebagaimana uraian di atas, penelitian terdahulu belum menunjukkan adanya kajian di pesantren berhubungan dengan pengembangan kurikulum berbasis kewirausahaan. Sementara dalam praktik di Pesantren Roudhatul Khuffadz dengan usia yang relatif muda, masih berkisar umur 13 tahun ke atas, anak-anak muda ini telah diberikan pengenalan bagimana mewujudkan semangat mandiri dengan wirausaha. Tentu pesantren tidak secara langsung mengiplementasikan itu sejak hari pertama tetapi mendesain program-program secara bertahap. Pada akhirnya, ketika seorang santri lulus dan saatnya kembali ke masyarakat, mereka memiliki keterampilan untuk hidup di tengah- 
tengah masyarakat. Tanpa perlu menjadi beban bagi masyarakat itu sendiri.

\section{Metode Penelitian}

Kajian ini menggunakan pendekatan kualitatif dalam memahami obyek penelitian. Adapun jenis kualitatif yang digunakan adalah studi kasus, pemilihan pendekatan dan jenis penelitian ini didasarkan atas masalah penelitian. Pendekatan kualitatif berupaya mendeskripsikan makna data atau fenomena yang ditangkap, dengan mengajukan bukti-bukti. Pemaknaan fenomena bergantung kepada analisis peneliti (Spradley: 1980), dimana untuk mendapatkan jawaban dari pertanyaan penelitian diperlukan data-data yang berupa aktivitas lapangan, pernyataan santri, guru, dan kiyai. Demikian pula dokumen yang berkenaan dengan kebijakan dan aktivitas dalam pesantren. Penelitian dilaksanakan di Pesantren Rodhotul Khuffadz, Kabupaten Sorong, Provinsi Papua Barat. Pesantren ini dalam tinjauan observasi awal, telah menggunakan prinsip-prinsip kewirausahaan dalam melaksanakan aktivitas pembelajaran. Untuk itu adanya kesesuaian antara masalah penelitian dengan subyek kajian, sehingga peneliti memilih untuk melakukan kajian di tempat berkenaan.

Keunikan pesantren ini dapat diamati sebagai satu hal yang khas dalam tradisi pendidikan Islam. Dimana pendidikan Islam lebih menekankan kepada penguasaan pengetahuan agama semata. Keadaan ini memenuhi syarat untuk dilaksanakannya jenis studi kasus. Dimana kondisi seperti ini merupakan gambaran naturalistik yang tidak dilakukan dalam lembaga lain yang sejenis. Kedua hal tersebut dijadikan alasan untuk menggunakan studi kasus dalam penelitian ini. Penggunaan studi kasus dalam pandangan Sukmadinata (2012:78-79) adalah metode untuk menghimpun dan menganalisis data berkenaan sesuatu kasus. Sehingga arah studi kasus adalah untuk mengkaji kondisi, kegiatan, perkembangan dan faktor-faktor penting yang terkait dan menunjang kondisi dan perkembangan tersebut.

Sementara, untuk mendapatkan data maka dilakukan pengamatan, wawancara dan analisa dokumen. Dalam pengumpulan 
data digunakan instrumen pengumpulan data. Pelaksanaan pengamatan digunakan panduan pengamatan, dalam wawancara digunakan pedoman wawancara. Untuk analisa digunakan kerangka analisis dokumen. Ketika diperlukan data tambahan, maka observasi dilaksanakan secara berkesinambungan. Dalam usaha tetap menjaga naturalistik lingkungan, maka pengamatan yang dilakukan dengan tidak menyertakan diri dalam kegiatan-kegiatan yang berlangsung. Peneliti menjadi orang asing dan tidak terlibat dalam pelbagai aktivitas pondok. Jika data yang didapatkan dari wawancara belum memadai, maka digunakan wawancara mendalam. Tidak saja terhadap kiyai, tetapi juga beberapa orang guru. Demikian pula santri. Ketiga subyek ini bahkan dilakukan secara berulangulang. Pengumpulan data dilaksanakan selama tiga bulan yaitu Februari sampai Juni 2012. Untuk memastikan keabsahan data, maka dilakukan tiga teknik. Pertama, pengumpulan data diperpanjang dari Juni sampai September 2012. Kedua, ketekunan pengamatan. Data-data yang dikumpulkan melalui pengamatan dicek kembali secara rinci dan teliti. Ketiga, pengecekan sejawat. Dilakukan konsultasi dan diskusi dengan rekan sejawat, guru besar dan pakar pendidikan Islam untuk digunakan sebagai pertimbangan (Angrosino dan de Perez: 2000).

Sebelum mengunjungi lapangan yang menjadi subyek penelitian, peneliti terlebih dahulu menghimpun kerangka acuan dalam rangka memandu pengumpulan dan analisis data. Sebagaimana diuraikan Bogdan dan Biklen (1983) bahwa proses ini akan merupakan rangkaian untuk menata bingkai kerja berdasarkan organisasi pemikiran dengan berbasis pada nalar, sebagai rangkaian pendalaman atas realitas, ataupun mengacu kepada teori, konsep dan pandangan tertentu. Berdasarkan bingkai kerja teoritis ini, penelitian mengumpulkan bukti-bukti, baik yang berkaitan dengan interaksi santri dan pengelola pesantren, lingkungan pesantren yang mendukung implementasi kewirausahaan sebagai bagian dari proses pendidikan. Dengan membuat bingkai kerja teoritis ini, maka data yang dikumpulkan sekaligus analisisnya dipandu oleh kerangka tersebut. 


\section{Analisis}

\section{Penetapan Kurikulum Pesantren}

Menjadi satu kelaziman, penetapan kurikulum pesantren senantiasa mengacu kepada masing-masing kiyainya. Ini pula yang terjadi dalam konteks pesantren Roudhatul Khuffadz. Berbeda dengan kurikulum madrasah, secara kelembagaan mengikuti kepada ketentuan perundang-undangan yang ditetapkan pemerintah. Sementara dalam pelaksanaan kegiatan pesantren, selalu dijalankan berdasarkan kapasitas kiyai. Untuk menjamin mutu pendidikan di pesantren Roudhatul Khuffadz secara berkala, diskusi dan penetapan kurikulum tidak berada secara mutlak di tangan kiyai tetapi secara bertahap dibicarakan dalam dewan guru (asatidz). Setelah mendapatkan pembahasan, pertimbangan dan konsultasi diantara para guru, maka kurikulum tersebut dibahas secara bersama dalam bentuk seminar dengan santri-santri senior, termasuk dengan pembina pesantren. Setelahnya kemudian diserahkan ke kiyai. Dengan pertimbangan guru yang masuk dalam jajaran pengelola pesantren, kiyai kemudian melakukan penelaahan kurikulum tersebut. Tahap akhir, kurikulum dibahas di jajaran pengurus yayasan untuk selanjutnya ditetapkan sebagai ketetapan yayasan untuk dijalankan kiyai yang didalamnya masuk sebagai pengurus yayasan.

Faktor utama yang menjadi pertimbangan penetapan kurikulum tersebut adalah kesesuaian dengan kondisi masyarakat sekitar. Dimana pesantren berlokasi. Tidak dilihat secara sempit, konteks kabupaten Sorong tetapi Papua secara umum. Kondisi alam Papua yang terdiri atas pantai dan pegunungan dijadikan sebagai pertimbangan. Walaupun Sorong merupakan wilayah yang lebih fokus pada perniagaan antar wilayah tetapi santri yang belajar di pesantren Roudhatul Khuffadz berasal dari pelbagai latar belakang yang tersebar di wilayah Papua Barat, tidak saja berasal dari Sorong. Kemudian acuan yang digunakan bahwa dalam hal kebutuhan keseharian masyarakat berada dalam lingkup pertanian, peternakan dan perikanan. Oleh karena itu kemudian tiga unsur ini digunakan secara bersama-sama dalam lingkungan pesantren. Di samping sebagai kelangsungan pengembangan pesantren, usaha-usaha yang ada merupakan proses pembelajaran bagi santri. 
Ada stigma yang berkembang dalam masyarakat Sorong Raya bahwa pesantren adalah panti asuhan. Ketika ada seorang muslim akan menyalurkan zakat atau sumbangan, maka pesantren menjadi pilihan. Demikian pula ketika pelaksanaan buka puasa atau aqiqah serta kegiatan keagamaan lainnya. Santrilah yang kemudian menerima penyaluran dari kegiatan-kegiatan sosial. Dengan pertimbangan ini, maka pesantren Roudhatul Khuffadz berupaya melakukan pemberdayaan. Salah satunya dengan membekali santri keterampilan dalam aktivitas sehari-hari. Dimana alam Papua memberikan peluang untuk bertani, dan melaut untuk mencari ikan. Berdasarkan keadaan lingkungan ini, maka pesantren memilih untuk melakukan pengembangan keterampilan pertanian dengan menggandengkan juga keterampilan pengelolaan peternakan dan perikanan. Hasil yang diharapkan, peran alumni pesantren mampu menjadi pionir dalam masyarakatnya dimana dia bermukim. Pola kehidupan yang ada selama ini hanya pada menohok sagu dan memancing ikan. Beberapa suku seperti Kokoda dan Inawatan memilih untuk menjual kayu dan batu karang. Seiring dengan pertambahan jumlah penduduk dan juga wilayah Papua tidak semata-mata didiami oleh suku yang berasal dari Papua saja, maka pengolahan tanah dengan teknik bertani secara permanen perlu dilakukan untuk memenuhi kebutuhan pangan.

Untuk pertanian, santri mulai diperkenalkan bagaimana menanam cabe, ketela, ubi jalar dan berbagai jenis tanaman lainnya. Demikian pula tanaman jangka panjang seperti padi, pisang dan juga tanaman jati putih. Secara bergilir, santri dengan koordinasi santri senior memantau tanaman-tanaman ini. Ketika hasilnya sudah dapat dipanen, maka santripun kemudian dengan koordinasi pembina yang ada dalam lingkungan pesantren mencari kemitraan dengan pedagang atau pengusaha setempat. Hasilnya digunakan untuk kebutuhan sehari-hari santri dan juga untuk pengembangan sarana dan prasarana pesantren. Secara bertahap ketika keuangan memungkinkan, kiyai membeli tanah masyarakat sekita untuk perluasan lahan pondok. Sebelumnya hanya sekitar 200 meter. Sekarang ini mencapai 7 hektar. Seiring dengan bertambahnya sumber daya serta minat kepada pendidikan pesantren, maka yayasan menambah fasilitas belajar. Demikia pula ketika didirikan 
2006, hanya mengelola madrasah ibtidaiyah, 2011 mulai dijalankan madrasah tsanawiyah.

\section{Proses Pendidikan}

Dalam proses ini, pendidikan tidak dijalankan di dalam kelas saja. Pada proses pendidikan di madrasah, maka kelas menjadi bagian utama. Sebaliknya ketika di luar pola pendidikan formal, justru unsur-unsur yang ada adalah kiyai, santri, masjid, sawah, kebun, kandang, kolam dan kitab kuning. Di saat santri sudah menyelesaikan pendidikan di bangku sekolah, maka saatnya mereka kembali ke asrama dan menunaikan shalat serta menikmati makanan. Selanjutnya mereka beristirahat sampai waktu shalat Ashar. Usai shalat, mereka kemudian memeriksa tanaman di sawah atau kebun, mengecek hewan yang ada di kandang, lalu memberi makan ikan dan membesihkan kolam. Tanaman yang dibudidayakan antara lain cabe, padi, ketela pohon. Sementara hewan ternak yaitu sapi, ayam kampung dan bebek. Adapun ikan hanya ada dua jenis yaitu ikan nila dan ikan lele. Masing-masing berbeda kolam. Kolam nila ditempatkan di dekat masjid, dimana air sisa wudhu mengalir ke kolam ikan. Adapun lele ditempatkan di bagian belakang pondok. Air dan kotoran yang berasal dari ayam dan bebek akan mengalir ke kolam lele.

Walaupun telah dilakukan pengembangan kurikulum berdasarkan pertimbangan-pertimbangan di atas, pesantren Roudhatul Khuffadz tidak melepaskan diri dari tradisi pesantren yang berbentuk sorogan dan wetonan. Seusai shalat maghrib, santri mengaji ke ustadz-ustadz sesuai dengan tingkatan kitab yang ditekuni. Hanya saja, kategorisasi tidak menggunakan kitab-kitab yang dikaji di pesantren salaf. Tetapi pembelajaran bahasa menggunakan model pesantren Gontor. Sementara kajian kitab hanya ditekankan kepada kitab ulumul quran, hadis, dan ushul al-fiq. Pada tingkatan ibtidaiyah, masih diajarkan fiqh. Tetapi di saat santri sudah menjejaki kelas tsanawiyah, mereka tidak lagi diajarkan produk hukum. Namun lebih kepada bagaimana nash al-Quran mendasari proses istibath hukum tersebut.

Prinsip relevansi yang berkaitan dengan kebutuhan masyarakat sekitar pesantren menjadi ukuran utama penetapan kurikulum 
pesantren. Namun demikian, tetap disadari oleh pengurus yayasan bahwa partisipasi dalam dunia kerja dan industri merupakan jawaban dari persaingan saat ini. Tetapi dalam aspek kehidupan manusia, tidak saja berupa kebutuhan jasmaniah semata-mata tetapi perlu juga menjadi perhatian yaitu kebutuhan akan etika, dalam hal ini Islam sebagai jalan hidup. Elemen utama pendidikan adalah menyediakan spirit keagamaan tanpa tertinggal dengan perkembangan terkini. Pesantren dibangun atas analisis lingkungan sekaligus merupakan jawaban sosial untuk masyarakat.

Sebagai program pengembangan, kegiatan yang dijalankan pesantren bergantung kepada proses. Dengan metode yang dijalankan secara formal, praktis, dan fokus pada penguasaan keterampilan. Tidak saja berupaya keterampilan teknis sesuai dengan bidang yang ditekuni, tetapi lebih dari itu. Keterampilan manusiawi dimana secara langsung mereka mendapatkan keterampilan yang berhubungan dengan kerjasama secara kelompok, memahami proses kerja dalam tim, merancang alur kegiatan, dan berpartisipasi dalam pelaksanaan keseluruhan komponen. Ini berarti pada saat yang sama terjadi pertumbuhan kepribadian peserta didik. Dalam bahasa pesantren disebut dengan pengetahuan, sikap, dan keterampilan. Pengetahuan didapatkan secara langsung dari lapangan. Kadang juga dikonfirmasi dengan pengalaman orang lain yang bersumber dari buku atau bacaan lain. Sementara sikap berhubungan dengan relasi santri dengan kelompok kerjanya. Sementara paduan antara pengetahuan dan sikap akan melahirkan keterampilan.

Secara berkala santri diajak berdiskusi untuk memberikan paparan pengalaman dalam beraktivitas. Program ini juga dimaksudkan untuk berbagi beberapa hal yang ditemukan santri dalam kegiatan sehari-hari. Ada juga keterampilan yang tumbuh secara alami yaitu keterampilan berbicara di depan umum, menyampaikan ide dan kemampuan untuk bertanya. Dalam lingkungan pesantren mereka akan berbagi dengan kelompok lain. Di saat kelompok tani terdekat melaksanakan kegiatan konsultasi atau penyuluhan, maka beberapa santri senior diutus untuk ikut menimba ilmu. Ketika dilaksanakan pertemuan mingguan, santri yang pulang dari kegiatan kelompok tani diminta untuk berbagi informasi. Dalam konteks ini, santri tidak hanya belajar bagaimana bekerja dalam tim tetapi 
juga berusaha untuk senantiasa berbagi dengan anggota tim. Hasilnya akan muncul perbaikan berkelanjutan berdasarkan pengalaman nyata di lapangan.

Pembelajaran berlangsung dalam kondisi dimana santri diberikan kesempatan untuk melakukan pembelajaran yang berpusat pada aktivitas. Guru bukanlah menjadi sumber utama proses pembelajaran tetapi hanya menjadi pendamping. Maka hasil yang diharapkan dengan teknik ini adalah tumbuhnya motivasi belajar santri yang mendorong kepada kreatifitas. Lalu secara mandiri mereka akan menemukan jawaban-jawaban dari aktivitas ketika menghadapi suatu masalah. Namun ini dilaksanakan dengan pengawasan ketat diantara santri. Bukan bermaksud membatasi tetapi tetapi demi kesinambungan hasil yang diharapkan. Pendekatan ini dijalankan karena teknik instruksional yang dijalankan bukan semata-mata untuk kepentingan praktik tetapi juga untuk kelangsungan ekonomi pesantren. Sebagai proses pembelajaran, maka lingkungan pesantren memberikan keluasan kepada santri untuk tetap berekspresi sesuai bakat dan minat.

Walaupun kurikulum memberikan tempat yang istimewa untuk tumbuhnya semangat kewirausahaan tetapi tidak ditutup peluang bagi santri untuk mengasah kemampuan berbahasa asing seperti bahasa Arab dan Inggris. Di samping itu pula diperkenalkan dengan drum band. Ekstra kurikuler lain juga dijadwalkan secara khusus, antara lain olahraga berupa sepak bola, tennis meja, badminton dan pencak silat. Praktik kewirausahaan dalam bentuk pertanian, perikanan dan peterkanan semata-mata membekali santri untuk tahap berikutnya ketika berada di masyarakat. Namun pengembangan pola fikir dan jasmani juga tetap mendapat perhatian yang seimbang. Kurikulum madrasah tetap memberikan komponen pendidikan jasmani, ditambah dengan alokasi untuk berolahraga dalam kurikulum kepesantrenan.

\section{Kurikulum yang Terintegrasi}

Hasil penelitian menunjukkan bahwa di samping ada kurikulum yang berbasis pada madrasah, pesantren Roudhatul Khuffadz juga menerapkan konsep kurikulum kewirausahaan dalam proses pendidikan yang terintegrasi dengan pola pendidikan pesantren. 
Proses perkembangan yang berbeda-beda kemudian mendorong wujudnya pesantren dengan pola yang sangat khas jika dibandingkan dengan pesantren yang ada sebelumnya. Jika dibandingkan dengan temuan Mastuhu (1994) dengan melihat pesantren Gulukguluk, Sukerejo, Blok Agung, Tebu Ireng, Paciran, dan Gontor, maka pesantren Roudhatul Khuffadz relatif muda, dimana pendirian diawali sejak 2006. Dengan tuntutan modernisasi, maka pesantren Roudhatul Khuffadz termasuk melakukan adaptasi lingkungan sesuai dengan keperluan setempat. Penjelasan seperti ini juga diuraikan Raihani (2012). Dia memandang pesantren telah melakukan adaptasi lingkungan, menyertakan nilai-nilai demokratis, memperkuat pengembangan masyarakat, serta mengakui adanya perbedaan.

Sementara itu kondisi pesantren yang berada di wilayah minoritas muslim memberikan kesempatan untuk melakukan penguatan, agar supaya santri seusai umur sekolah dapat dibekali dengan keterampilan dalam menjalani kehidupan sehari-hari. Pada saat santri menamatkan pendidikan di pesantren, ada kesempatan yang terbuka lebar. Sehingga alumni pesantren akan melakukan kiprah yang beragam sesuai dengan pilihan masing-masing. Hasil penelitian ini senada dengan penelitian Mesquita (2012) bahwa di Portugal, tuntutan lingkungan kemudian mendorong lembagalembaga pendidikan untuk menerapkan kurikulum yang berorientasi kepada kewirausahaan. Lingkungan menjadi faktor minor dalam pengembangan pendidikan.

Program pendidikan dan pelatihan juga diselenggarakan oleh lembaga pendidikan lain, tidak hanya pesantren. Kesenjangan antara permintaan tenaga terampil untuk mengisi lapangan kerja menjadi alasan untuk memecahkan ketimpangan tersebut. Berbeda dengan pesantren, pelaksanaan pendidikan dan pelatihan didorong atas semangat memberikan relevansi pendidikan dengan perkembangan dinamis terkini. Proses pendidikan yang ada dalam rangka menyiapkan keberadaan santri ketika berada di masyarakat pada saatnya. Praktik yang sama dijalankan di Norwegia (Mandt:2008). Pendidikan dibingkai para peserta didik berasal dari beragam latar belakang budaya dan status sosial. Dengan demikian, pendidikan diarahkan untuk mencapai tantangan dan tujuan yang berbeda sesuai dengan 
keadaan personal masing-masing murid. Program pendidikan tertentu belum pasti diperlukan oleh murid-murid, walaupun berada dalam waktu yang sama. Bentley College di Boston, Amerika Serikat memberikan bukti bahwa perubahan secara cepat dapat diatasi dengan adaptasi kurikulum yang tepat (Fedorowicz dan Gogan: 2001).

Kekhasan pesantren yang juga tetap bertahan sampai kini, termasuk dalam konteks wilayah Papua dimana pesantren selalu menjadi bagian masyarakat. Bahkan pesantren kemudian meleburkan diri dalam pembangunan masyarakat. Hasil penelitian ini sama dengan penelitian yang dilaksanakan (Sirry:2010). Perhatian pesantren sekarang ini sampai isu-isu terkini seperti kewirausahaan. Tidak saja itu bahkan wacana berkenaan dengan gender juga sudah menjadi bagian dinamika pesantren (Srimulyani:2008). Walaupun terjadi gerakan-gerakan radikalisme dalam konteks Indonesia, tidak ada satu bukti dan putusan hukum yang final mengenai keterlibatan pesantren dalam huru-hara tersebut (Klinken:2007). Pesantren menjadi rujukan fatwa hukum. Walaupun pesantren Roudhatul Khuffadz tidak secara khusus mengajarkan fiqh tetapi dengan keterlibatan santri dalam hal kegiatan-kegiatan kemasyarakatan memberikan kesempatan berinteraksi dengan lingkungan sekitar. Dalam aktivitas ini, pesantren sebagaimana dalam penelitian Faulconbridge (2010) bahwa adanya interaksi dan kolaborasi antara lembaga pendidikan dengan lingkungan akan memberikan dampak positif bagi pengembangan masyarakat. Pesantren juga berperan sebagai salah satu wahana untuk mendiskusikan putusan-putusan hukum.

Pesantren hadir dalam kehidupan untuk menjadi kekuatan pendukung bagi kelangsungan masyarakat. Bukan untuk menjadi pesaing dalam sistem pendidikan yang ada. Justru dengan keberadaan ini, menjadi sinergitas antara pesantren dan pemerintah. Tentu yang akan menikmati hasil dari kemitraan ini adalah masyarakat sendiri. Kewujudan pesantren di tahap awal terkadang belum memerlukan pendampingan. Tetapi pada fase selanjutnya, perlu ada pengembangan dan kesefahaman bersama. Pengembangan kurikulum, standarisasi tenaga pengajar, proses pembelajaran dan luaran pesantren harus dipantau oleh lembaga yang berwenang. Dengan demikian akan meningkatkan akuntabilitas pesantren. 
Aspek religiusitas pesantren tetap perlu mendapatkan perhatian utama. Keberadaan kemitraan yang diuraikan tadi semata-mata sebagai pengembangan dari aspek madrasah. Adapun dinamika pesantren yang menjadikan lingkungan sebagai unsur pembelajaran secara khas perlu diselaraskan dengan prinsip-prinsip pembelajaran mutakhir.

Akhirnya, sejak awal tidak dikenal istilah kurikulum dalam pesantren. Namun dengan adaptasi terhadap formalitas pendidikan dalam bentuk sekolah kemudian dilakukan pengembangan kelembagaan pesantren dengan memasukkan sistem sekolah sebagai bagian tradisi kepesantrenan. Kontrol pemerintah dalam bentuk akreditasi madrasah mensyaratkan kelengkapan ini wajib. Dengan demikian, sesungguhnya pola pendidikan yang dilakukan pesantren lebih kepada pola pembinaan yang berkesinambungan di luar jam pelajaran sekolah. Pesantren dengan integrasi dalam bentuk lingkungan yang ditopang dengan asrama memungkinkan pembelajaran kemudian berlangsung selama $24 \mathrm{jam}$. Semua aktifitas justru disebut sebagai proses pendidikan. Disinilah pesantren kemudian menemukan kesempatan dalam membangun kapasitas seorang santri. Aspekaspek kehidupan fundamental sebagai sarana belajar santri sebagai proses mempersiapkan untuk kehidupan nyata.

\section{Kesimpulan}

Salah satu faktor yang menjadi pertimbangan utama dalam proses pembentukan kurikulum adalah kesesuaian lingkungan dengan institusi pendidikan. Pesantren Roudhatul Khuffadz membuktikan bahwa ketika lingkungan sekitar pesantren memerlukan keterampilan dalam hal pertanian, peternakan, dan perikanan, maka pesantren mewadahi kebutuhan itu dengan mengintegrasikan dalam pendidikan formal. Pola pengembangan yang dilakukan tidak saja dalam bentuk kurikulum. Bahkan sampai pada metode pembelajaran. Dimana santri terlibat secara langsung dalam proses pembelajaran. Corak pesantren yang menjadi pilar dalam pembelajaran keagamaan bahkan diperkuat dengan adanya usaha menggandengkan prinsip-prinsip kewirausahaan. 
Pesantren Roudhatul Khuffadz bukanlah yang pertama melakukan inovasi dan kreativitas seperti ini. Tetapi pesantren lain sudah melakukan dalam skala masing-masing. Hanya saja, faktor kesadaran lingkungan yang membawa lembaga ini bisa menjadi acuan. Interaksi, komunikasi dan konteks situasional menjadi faktor lain dalam pembentukan kurikulum pesantren. Termasuk adanya aspek sosio-kultural yang dinamis sehingga mendorong proses pengembangan kurikulum. Penelitian ini, membatasi penelusuran data pada skala pengembangan kurikulum dan pendekatan pembelajaran. Belum melakukan kajian pada metode pembelajaran, teknik dan strategi yang digunakan dalam implementasi kurikulum yang telah dikembangkan. Untuk itu, peneliti selanjutnya perlu mengidentifikasi siklus selanjutnya dalam pembelajaran kewirausahaan. Demikian pula faktor sosio-kultural yang mendasari sehingga pengembangan kurikulum dilakukan

\section{Daftar Pustaka}

Angrosino, Michael V. dan de Perez, Kimberly A. May. 2000. "Rethinking Observation From Method to Context". Dalam Handbook Qualitative Research. Edisi Kedua. Thousand Oaks: Sage Publications, Inc.

Basyir, Zainul Fuad. 1999. KH Imam Zarkasyi Tentang Modernisasi Pondok Pesantren: Studi Kasus di Pondok Pesantren Modern Gontor. Tesis UMM. Malang: Program Pasca Sarjana.

Bogdan, R. C. dan Biklen, S. K. 1982. Qualitative Research for Education: An Introduction to Theory and Methods. Boston, MA: Allyn and Bacon, Inc.

Boland, B. J.. 1985. Pergumulan Islam di Indonesia. Jakarta: Grafiti Pers.

Buresh, Scott Allen. 2002. Pesantren-based Development: Islam, Education, and Economic Development in Indonesia. Disertasi: University of Virginia, Amerika Serikat.

Dhofier, Zamakhsyari. 1982. Tradisi Pesantren: Studi tentang Pandangan Hidup Kyai. Jakarta: LP3ES.

Fatimah. 2011. Aktualisasi Dakwah Islam Kajian tentang Nilai-nilai Pluralisme Agama pada Masyarakat Kokoda. Sorong: 
Pustaka Rafana STAIN Sorong.

Fatimah. 2011. Islamisasi di Sorong Suatu Pendekatan Teknologi Komunikasi. Makassar: Membumi Publishing.

Faulconbridge, James R. 2010. "TNCs as embedded social communities: transdisciplinary perspectives". Critical Perspectives on International Business, Vol. 6, No. 4:273 290.

Fedorowicz, Jane dan Gogan, Janis L. 2001. "Fast-Cycle Curriculum Development Strategies for E-Business Programs: The Bentley College Experience". Journal of Education for Business, Vol. 76, No. 6:318-327.

Hamdi, S., Smith, B.J. 2012. "Sisters, Militias and Islam in Conflict: Questioning 'Reconciliation' In Nahdlatul Wathan, Lombok, Indonesia, dalam Contemporary Islam, Vol. 6, No. 1:29-43.

Huzain, Muhammad. 2010. Pendidikan Demokrasi-Humanis. Sorong: Pustaka Rafana STAIN Sorong.

Izfanna, D., Hisyam. 2012. "A Comprehensive Approach in Developing Akhlaq: A Case Study on The Implementation of Character Education At Pondok Pesantren Darunnajah". Multicultural Education and Technology Journal, Vol. 6, No. 2:77-86.

Jamhari. 2006. "Pesantren di Bali: Pendidikan Islam di Daerah Minoritas". Mencetak Muslim Modern. Jakarta: RajaGrafindo Perkasa.

Johansen, Vegard and Schanke, Tuva. 2012. "Entrepreneurship Education in Secondary Education and Training". Scandinavian Journal of Educational Research, Vol. 1:1-12.

Likewati, Wa Ode. 2011. Aktivitas Human Relations dalam Meningkatkan Motivasi Pegawai Kantor Kementerian Agama di Kabupaten Sorong. Makassar: Membumi Publishing.

Lukens-Bull, R.A. 2001. "Two Sides Of The Same Coin: Modernity And Tradition In Islamic Education In Indonesia". Anthropology and Education Quarterly, Vol. 32, No. 3:350-372.

Majelis Ulama Indonesia. 1986. Amanat Sejarah Ummat Islam Indonesia. Keputusan Rapat Paripurna ke II. Jakarta: Sekretariat MUI. 
Mandt, Gunnar. 2008. "The Quality Framework in Norway". Intercultural Education, Vol. 19, No. 2:177-182.

Mastuhu. 1994. Dinamika Sistem Pendidikan Pesantren: Suatu Kajian Tentang Unsur Dan Nilai Sistem Pendidikan Pesantren. Jakarta: INIS.

Mesquita, Leopoldo. 2012. "The Entrepreneurialisation of School Work as A Central Theme in Present Educational Changes: The Portuguese Case". Journal of Educational Administration and History, Vol. 44, No. 2:141-153.

O'Sullivan, Michael. 2006. "L’Université Sans Profession (The University Without Profession) The Privilege of the Conflict of the Faculties". Parallax. Vol. 12, No. 3: 112-124.

Permani, Risti.. 2009. The Economics of Islamic Education: Evidence from Indonesia. Tesis: University of Adelaide, Australia.

Pohl, F. 2006. "Islamic Education And Civil Society: Reflections On The Pesantren Tradition In Contemporary Indonesia". Comparative Education Review, Vol. 50, No. 3:389-409.

Raihani. 2012. "Report on Multicultural Education in Pesantren". Compare: A Journal of Comparative and International Education, Vol. 42, No. 4:585-605.

Rosiers, François Des., Dubé, Jean., dan Thériault, Marius. 2011. "Do Peer Effects Shape Property Values?". Journal of Property Investment \& Finance, Vol. 29, No. 4:510 - 528.

Saniotis, A. 2012. "Muslims and Ecology: Fostering Islamic Environmental Ethics". Contemporary Islam, Vol. 6, No. 2:155-171

Satir, Muhammad. 2011. Korelasi Pendidikan Agama Islam dengan Perilaku Agama Peserta Didik. Makassar: Membumi Publishing.

Sealey, Richard. Robson, Maurice., dan Hutchins, Trevor. 1997. "School and University Partnerships: Some Findings From a Curriculum development Project". Asia-Pacific Journal of Teacher Education, Vol. 25, No. 1:79-89.

Sirry, Mun'im. 2010. "The Public Expression of Traditional Islam: The Pesantren and Civil Society in Post-Suharto Indonesia". The Muslim World, Vol. 100, No. 1:60-77. 
Spradley, J. P. 1980. Participant Observation. New York, CA: Holt, Rinehart and Winston.

Srimulyani, Eka. 2008. "Pesantren Seblak of Jombang, East Java: Women's Educational Leadership". Review of Indonesian and Malaysian Affairs, Vol. 42, No. 1:81-106.

Sukman. 2010. Dakwah Islam di Kabupaten Raja Ampat: Suatu Tinjauan Teologis. Sorong: Pustaka Rafana STAIN Sorong.

Sunatar, Bambang. 2011. Tokoh Agama dan Politik Studi Kasus Keterlibatan Tokoh Agama dalam Politik di Sorong. Makassar: Membumi Publishing.

Tilaar, H.A.R. 2010. Paradigma Baru Pendidikan Nasional. Jakarta: Rineka Cipta.

Van Bruinessen, Martin. 1995. Kitab Kuning, Pesantren dan Tarekat. Bandung: Mizan.

Van Klinken, Geery. 2007. Communal Violence and Democratization in Indonesia: Small Town Wars". Contemporary Souteast Asia Series. London and New York: Routledge.

Vignato, S. 2012. Devices of Oblivion: How Islamic Schools Rescue 'orphaned' Children From Traumatic Experiences in Aceh (Indonesia)". South East Asia Research. Vol. 20, No. 2:239261

Widodo, Slamet. 2011. Yayasan Emeyodere dalam Pelayanan Pendidikan Masyarakat Kokoda di Kota Sorong. Sorong: Pustaka Rafana STAIN Sorong.

Ziemek, Manfred. 1986. Pesanten Dalam Perubahan Sosial. Jakarta: P3M.

Zuhairini, dkk., 1997. Sejarah Pendidikan Islam. Jakarta: Bumi Aksara. 